\title{
Diagnosis of the aromatic and medicinal plant sector in Morocco: Case of the cooperatives and associations of the Meknès-Tafilalt area
}

\author{
Mouhcine Fadil (***), Abdellah Farah (**), Taoufik Haloui (*,**) \\ \& Saâd Rachiq (*)
}

\begin{abstract}
Fadil, M., Farah, A., Haloui, T., Rachiq, S. Diagnosis of the aromatic and medicinal plant sector in Morocco: Case of the cooperatives and associations of the Meknès-Tafilalt area. Lazaroa 35: 155-165 (2014).

The cooperatives and associations in the medicinal and aromatic plant (MAP) sector are completely dependent on the pressure of market demand, and their products need to comply with required quality criteria and delivery time constraints. We conducted a survey of the activities of the cooperatives and associations involved in the production of genetic plant resources and their socioeconomic impact in order to identify the problems affecting this sector, and to improve the MAP's production conditions and the income of the marginalized rural population. This survey looked at 11 associations and cooperatives operating in the Meknès-Tafilalt area in Morocco. The results of the botanical survey identified 30 species from 12 families, exploited in their natural state for commercial use. The total annual production is 494 tons of dried plants. Rosemary is the most widely used, with $23 \%$ of the total production, $19 \%$ of which is produced by the Ajaâbou Cooperative. However, the exploitation of these species in their natural state is haphazard, and presents a threat to the sustainability of resources. The products are not properly identified, and few producers use good technical harvesting practices. To improve sustainable commercial potential and the competitiveness of the products, MAP cooperatives and associations should incorporate practical standards of quality, traceability, good collection and cultivation of the species.
\end{abstract}

Keywords: Cooperatives, Associations, Medicinal and Aromatic Plants, survey, socioeconomic impact.

Resumen: Fadil, M., Farah, A., Haloui, T., Rachiq, S. Diagnóstico del sector de plantas medicinales y aromáticas en Marruecos: cooperativas y asociaciones de Meknès-Tafilalt. Lazaroa 35: 155-165 (2014).

La existencia de cooperativas y asociaciones en el sector de las Plantas Medicinales y Aromáticas (PMA) es la prueba de la existencia de una demanda del mercado, así como de la necesidad de que la oferta de sus productos se realice de acuerdo a los criterios de calidad necesarios y suficientes que garanticen el suministro en tiempo deseado. Con el fin de identificar los problemas de este sector, mejorar la producción de los PMA y los ingresos de la población rural marginada, llevamos a cabo una investigación sobre las actividades de las cooperativas y asociaciones en el ámbito de los recursos fitogenéticos y socioeconómicos de tipo 'spin-off'. Esta encuesta abarcó a 11 asociaciones y cooperativas en la región de Meknes-Tafilalet en Marruecos, que operan en el sector del PMA. Los resultados del estudio botánico han permitido identificar 30 especies, incluidas en 12 familias, que son explotadas a partir de la flora espontánea para uso comercial. La producción anual es de 494 toneladas de planta seca. Entre todas las especies, el romero es el más utilizado con un $23 \%$ de la producción total. La cooperativa Ajaâbou ocupa el primer lugar en la producción de romero con un 19\% de la cantidad total producida. Sin embargo, la explotación de estas especies en su estado natural supone un importante riesgo para los recursos naturales, debido a que plantea una amenaza a la sostenibilidad de los mismos. En el aspecto técnico, los productos no logran alcanzar los objetivos de calidad, siendo difícil su identificación y, en la mayoría de los casos, no se cumplen las normas de recolección. el secado a la sombra es la forma más utilizada. Para mejorar el mercado sostenible y la competitividad de sus productos las cooperativas y las asociaciones del sector deben integrar la práctica de estándares de calidad, trazabilidad, y normas de buena recolección y cultivo de especies en la producción de PAM.

Palabras clave: Cooperativas, asociaciones, plantas aromáticas y medicinales, encuestas, impacto socioeconómico.

* Faculty of Science and Technology Fez Sais. Department of Biology, Laboratory of Functional Ecology and Environment. Sidi Mohamed Ben Abdellah University. PO Box 2202. Road Imouzzer. Fez 30000. Morocco. Email: fadil.mouhcine@gmail.com

** National Institute of Medicinal and Aromatic Plants. Laboratory of Medicinal, Aromatic Plants and Natural Substances. Sidi Mohamed Ben Abdellah University. PO Box 159. Taounate 34025. Morocco. 


\section{INTRODUCTION}

The particular orography of Morocco confers the country specific soils and climatic conditions that are very diversified and favorable for the development of a rich and varied flora, including an important potential in often endemic Medicinal and Aromatic Plants (MAP). Morocco, one of the countries of the Mediterranean region, has a genuine phytogenetic tank with 41 ecosystems and 7000 plant species, including 4500 species of vascular plants. Among this floristic diversity, 600 species are famous for their aromatic and traditional medicine use (ANON., 2006a).

However, only 280 plants are currently exploited (HMAmouchi, 1997). Morocco is one of the Mediterranean countries which have a long medical tradition and a traditional know of medicinal herbs (SCHERRER \& al., 2005; HSEINI \& al., 2007; SAHLI \& al., 2010). The exploitation of the potential of MAP became an important and promising sector for the country. Indeed, Morocco exports approximately the equivalent of 300 million dirhams in MAP in various forms, and approximately 165 million dirhams of essential oils. That is to say, a total of approximately 465 million dirhams (ANON., 2006a).

The activity makes possible to generate important incomes, to create thousands of work days, in particular for the wedged populations of the rural environment, and to consolidate their commercial balances.

The importance of this sector for the rural and marginalized populations pushed the State to create cooperatives and associations which operate in this sector in order to ensure a suitable exploitation of the resources, to encourage the private sector investment and to improve the living conditions of the local populations by making them profit from the added-value generated by the valorization and the transformation of MAP (ANON., 2008).

The Meknès-Tafilalt area remains an example that represents the commercial exploitation of MAP by the cooperatives and associations. This area was selected for the study because of its climatic and geographical diversity which led a remarkable botanical diversity. Several ethnobotanical studies, carried on the plants of this area, showed that certain species are used for the treatment of the diabetes (EDDOUKS \& al., 2002; TAHRAOUI \& al., 2007; EL AMRANI \& CHAKIR, 2010), hypertension (TAHRAOUI \& al., 2007), cardiac diseases (EDDOUKS \& al., 2002) and other illness (GoNZÁLEZ \& al., 2012; MARTínEZ-PORRES \& al., 2014).

However, the cooperatives and associations operating in the sector of MAP have neither managed to capitalize the potential of the these plants in the area to answer the increasing demand of the markets, nor to improve the incomes of the marginalized populations by a production of quality and a better integration of the sector. They have not yet managed to preserve the environment by a rational management of the aromatic resources, to support the marketing of MAP towards the growing markets, or optimize synergies between the various partners and initiatives being interested in the field of MAP. Moreover, the techniques of exploitation and transformation of MAP present several weak links, upstream and downstream the sector. Upstream, the systems of adjudication, exploitation and transformation often relate to mining and must be revised. Downstream, the sector does not have any price policy nor of technological survey of technological accompaniment and only large transformers take profit from this way of managing.

To improve the competitiveness and the capacity of the cooperatives and associations to support the sector of MAP by enhancing the richness of the local products of soil and improving the standard of living of the disadvantaged rural populations of this region, the diagnosis of the situation up and downstream the sector seems necessary. The present study aims at prospecting, analyzing and assessing the processes of the cooperatives and associations in the sector MAP from the point of view of the exploitation of phytogenetic resources richness and the socio-economic impact.

\section{MATERIALS AND METHODS}

\section{DESCRIPTION AND GEOGRAPHICAL LOCATION OF THE STUDY ZONE}

The Meknès-Tafilalt area constitutes one of the great areas of Morocco. It extends on a surface of 
$79210 \mathrm{~km}^{2}$, that is to say approximately $11 \%$ of the national surface (ANON., 1996). It is characterized by a diversity of the phytogenetic, climatic and hydro-geographical resources. In fact, the Meknès-Tafilalt region is characterized by a bioclimatic stage extending from wet in Ifrane (1100 $\mathrm{mm}$ of rain) to pre-saharian in Er-rachidia (250 $\mathrm{mm})$. Thus, one distinguishes different plains and zones favorable to agriculture (the plain of Saiss, the plain of Tigrigra, the oasis of the Ziz river and the plain of Tafilalet, the solid mass of Zerhoun, the plateaux of El Hajeb, the central plate, the middle atlas chain and the pre-saharian zone of Tafilalet) (Anon., 2000). These geographical distributions support the production of a very varied range of cultures (ANON., 1996).

Located upstream the watersheds, this area have been granted the status of a zone rich in water. However, because of the lack of necessary installations, the majority of these zones know increasingly worrying water deficits. The flows in the rivers are primarily generated by floods which are rare and violent (some risings a year). These floods are of short duration, but produce important volumes of water (El RHAFFARI \& al., 2008).

\section{INVENTORY AND DATA COLLECTION}

The analysis of the activities of the cooperatives and associations of the area of Meknès-Tafilalt in the sector of the aromatic and medicinal plants was conducted during the period from July to September 2010 and covered five provinces: Meknès, El Hajeb, Khenifra, Ifrane and Er-rachidia. In each province, we contacted associations and cooperatives (Table 1) operating in the sector of MAP. The total number was 11 associations and cooperati-

Table 1

Cooperatives and associations considered to diagnose the sector of MAP in the Meknès-Tafilalt area

\begin{tabular}{|c|c|c|c|c|c|}
\hline District & $\mathrm{N}$. & Name & Address & Year & Organism \\
\hline El Hajeb & 1 & Ayedji assoc. & Rural district Iqadar & 2004 & - \\
\hline \multirow[t]{8}{*}{ Khénifra } & 4 & MAP's develop. & Rural district EL & 2007 & National Initiative \\
\hline & & assoc. & Hammam Mrirt & & Human Development \\
\hline & & Ait Libio-Ait & Rural district Aït Ishak & 2009 & Participative project \\
\hline & & Waka coop. & & & MEDA \\
\hline & & & & & $\begin{array}{l}\text { Rural Developpement } \\
\text { average central Atlas } \\
\text { (Khenifra project) }\end{array}$ \\
\hline & & Ikiss coop. & $\begin{array}{l}\text { Tatéouine village } \\
\text { beside Midelt }\end{array}$ & 2005 & - \\
\hline & & El Khair assoc. & Ait Oufella village & 2006 & National Initiative \\
\hline & & & Rural district Itzer & & Human Development \\
\hline \multirow[t]{9}{*}{ Ifrane } & 5 & $\begin{array}{l}\text { Initiative of the } \\
\text { women coop. }\end{array}$ & $\begin{array}{l}\text { Hay essalam- Ifrane, } \\
\text { center of the female } \\
\text { cooperatives }\end{array}$ & 2006 & - \\
\hline & & EL Amal coop. & Rural district Aït & 2005 & - \\
\hline & & & Yahaya Ouälla Azrou & & \\
\hline & & & Toufestalt village & & Development \\
\hline & & Ajaabou coop. & & 2005 & Reinforcement Program \\
\hline & & & Rural district Aïn Louh & & Local Assoc. Coop. \\
\hline & & Achifae coop. & Rural district Bensmim & 2006 & - \\
\hline & & Prod. MAP & & & \\
\hline & & Temihdit & Témihdit & 2010 & - \\
\hline Er-rachidia & 1 & Tazemmourite assoc. & Rural district EL Khang & 2000 & - \\
\hline
\end{tabular}


ves. Then, we began the technical and socio-economic data-gathering within each organization. The investigation was performed on the basis of a questionnaire, which is a synthesis of other questionnaires from studies on the use of the phytogenetic socio-economic resources carried out in Morocco (Mehdioui \& KaHOUAdJi, 2007; LAHSISSENE \& KAHOUADJI, 2010; El RHAFFARI \& al., 2008).

The questionnaire states the coordinates of the organization contact and those of the informant, the identification of the exploited species, the type of harvest and the authorization of the concerned directions. Regarding the socio-economic inventory, we considered the prices, quantities produced and all information about the market and the social status of the owners. In addition, we took into account the analysis of the technical processes namely: the modes of treatment of the plants, the kinds of products and environmental conditions, the qualification of staff, the equipment used, the quality aspect, the traceability and biological certification.

\section{RESULTS AND DISCUSSION}

The investigation covered 11 cooperatives and associations in the area of Meknès-Tafilalt. These organizations operate in the sector of the aromatic and medicinal plants by exploiting and marketing the potentially available species in this area. The main results of the questionnaire are summarized in Table 2.

\section{IDENTIFICATION OF THE EXPLOITED SPECIES}

Various species are frequently exploited by the cooperatives and associations of this area. There are about 30 species belonging to 12 families (Table 3). Thus, the family of Lamiaceae is very exploited with a number of 10 species: Salvia officinalis L., Lavandula angustifolia Mill.., L. stoechas L., Thymus vulgaris L., Origanum vulgare L., Mentha spicata L., M. piperita L., M. pulegium L., Melissa officinalis L. and Rosmarinus officinalis L. The family of Asteraceae is represented by five exploited species: Calendula offi- cinalis L., Santolina rosmarinifolia L., Matricaria chamomilla L., Anacyclus pyrethrum L. and Artemisia herba-alba Asso. Apiaceae is represented by four exploited species: Pimpinella anisum L., Cuminum cyminum L., Foeniculum vulgare Mill. and Carum carvi L. By only two species is represented Fabaceae: Trigonella foenum-graecum L. and Medicago sativa L. Finally with only one species we can mention: Cupressaceae ( $\mathrm{Ju}$ niperus communis L.), Geraniaceae (Pelargonium capitatum Ait.), Iridaceae (Iris germanica L.), Lythraceae: (Lawsonia inermis L.), Papaveraceae (Papaver rhoeas L.), Rutaceae (Citrus aurantium L.), Verbenaceae (Verbena officinalis L.), Rosaceae (Rosa centifolia Mill.) or Chenopodiaceae (Chenopodium ambrosioides L.).

All these exploited species show the significant phytogenetic wealth not only in the MeknèsTafilalt area, but in Morocco in general (BENABID, 2000). To face the increasing demand for this wealth of phytogenetic resources, the use of sustainable harvesting methods is detrimental. (WAHID, 2012).

\section{TYPE OF HARVEST OF THE EXPLOITED SPECIES}

The results of the inventory near the operators show that most species collected for marketing are of spontaneous rather than cultivated origin. The Figure 1 shows that the exploitation of the species from crop fields is low (34\%) in comparison with those in natural state (wild, 66\%). This type of harvest adopted by cooperatives and associations can lead to dramatic decrease in natural resources. Caution should be exercised by the operators in the region to operate the MAP species. Especially since previous studies have shown that the consumptive use of species for commercial purposes may lead to overexploitation, genetic erosion and finally extinction, especially if such use is not wisely managed. (CAUVIN \& al., 1997; WAHID \& al., 2009, 2010).

For sustainable exploitation, improving productivity, producing the sufficient quantity and quality required, and respecting the constraints of delivery, cooperatives and associations in the sector of MAP should incorporate the cultivation of genetically improved species well suited to the 


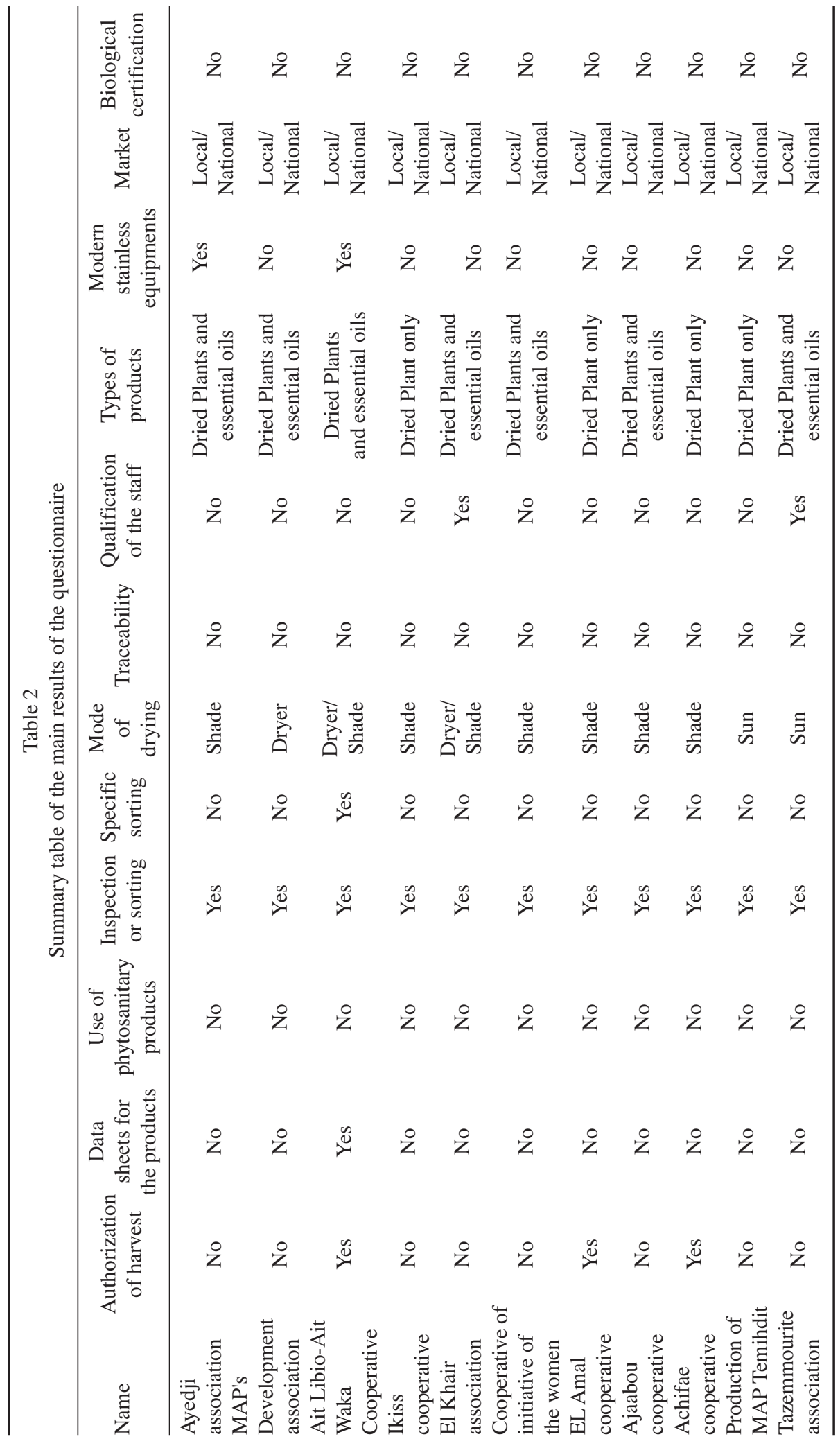


Table 3

Main species exploited by the cooperatives and associations of the Meknès-Tafilalt area for marketing

\begin{tabular}{|c|c|c|c|}
\hline Family & English name & Scientific name & Vernacular name \\
\hline \multirow{10}{*}{ Lamiaceae } & Sage & Salvia officinalis L. & Salmia; Tilsas; Tamazzût \\
\hline & Lavender & Lavandula angustifolia Mill. & khzama beldiya \\
\hline & Common thyme & Thymus vulgaris $\mathrm{L}$. & z'îtra; Azukenni \\
\hline & Oregano & Origanum vulgare L. & Zâtar \\
\hline & Lavender Stoechade & Lavandula stoechas L. & Halhal \\
\hline & Spearmint & Mentha spicata $\mathrm{L}$. & Naâna lbeldi \\
\hline & Peppermint & Mentha piperita $\mathrm{L}$. & Naâna felfli \\
\hline & Lemon Balm & Melissa officinalis L. & Hbak tranj \\
\hline & Pennyroyal & Mentha pulegium L. & Fliou \\
\hline & Rosemary & Rosmarinus officinalis L. & Azir; Yazir \\
\hline \multirow[t]{5}{*}{ Asteraceae } & Pot Marigold & Calendula officinalis L. & Jemra; Ahmer rras; Azwiwel \\
\hline & Santoline & Santolina rosmarinifolia $\mathrm{L}$. & Ouezouaza;Tayrart \\
\hline & Chamomile & Matricaria chamomilla L & Babounj \\
\hline & Pyrethrum & Anacyclus pyrethrum L. & Tignest; Aoujdem \\
\hline & Sagebrush & Artemisia herba-alba Asso. & Chih; Izri \\
\hline \multirow[t]{4}{*}{ Apiaceae } & Green Anise & Pimpinella anisum $\mathrm{L}$. & Habbet hlawa \\
\hline & Cumin & Cuminum cyminum L. & Kamoun \\
\hline & Common Fennel & Foeniculum vulgare Mill. & Nafaâ; Bessbass; Irden \\
\hline & Caraway & Carum carvi $\mathrm{L}$. & Karwiya \\
\hline \multirow[t]{2}{*}{ Fabaceae } & Fenugreek & Trigonella foenum-graecum $\mathrm{L}$. & Halba; Tifîdas \\
\hline & Alfalfa & Medicago sativa $\mathrm{L}$. & Fassa \\
\hline Rosaceae & Rosebush & Rosa centifolia Mill. & Lward lbeldi \\
\hline Chenopodiaceae & Wormseed & Chenopodium ambrosioides L. & Mkhinza \\
\hline Cupressaceae & Juniper & Juniperus communis L. & Âraâr \\
\hline Geraniaceae & Geranium Rosat & Pelargonium graveolens L. & Ifer laâtar \\
\hline Iridaceae & Iris & Iris germanica $\mathrm{L}$. & Tafzout \\
\hline Lythraceae & Henna & Lawsonia inermis L. & Henna \\
\hline Papaveraceae & Poppy & Papaver rhoeas $\mathrm{L}$. & Bellamane \\
\hline Rutaceae & Petitgrain & Citrus aurantium L. & Range \\
\hline Verbenaceae & Verbena, Vervain & Verbena officinalis $\mathrm{L}$. & Lwiza \\
\hline
\end{tabular}

environmental conditions of the region (WAHID \& al., 2012) They also should be able to master the agricultural cultivation techniques (irrigation system, irrigation amounts, ...)

\section{AUTHORIZATION OF HARVEST AND DATA SHEET OF THE EXPLOITED SPECIES}

The inventory results show that only $27 \%$ of farmers have permission from the sector officials to harvest the species in natural state (Figure 1). In addition, the vast majority of farmers do not exercise good collection practices: only three out of eleven cooperatives have the data sheet of collection of the exploited species. This shows that the organization of cooperatives and associations is still unregulated and illegal. This practice of co- llecting contributes more to the depletion of the natural resource wealth of MAP and therefore to lowering its economic value.

\section{ANNUAL MASS PRODUCTIONOF THE EXPLOITED SPECIES}

The total annual production of all species operated by cooperatives and associations in the region is about 494 tons of dried plants (Table 4). This amount is very small given the richness of this area, in number and types of phytogenetic resources. According to the annual quantities of harvested species, we note that the rosemary (Rosmarinus officinalis) and chamomile (Matricaria chamomilla) are the most productive, each with an annual production of 117 and 72 tons / 
Table 4

Annual produced quantity of the species exploited by the cooperatives and associations of the Meknés-Tafilialt area based in dried plant

\begin{tabular}{ll}
\hline Exploited species & $\begin{array}{l}\text { Prod. Quantity } \\
\text { (kg/year) }\end{array}$ \\
\hline Rosmarinus officinalis & 117000 \\
Matricaria chamomilla & 72000 \\
Calendula officinalis & 50000 \\
Melissa officinalis & 43000 \\
Lavandula officinalis & 35600 \\
Thymus vulgaris & 34000 \\
Artemisia herba-alba & 32000 \\
Mentha pulegium & 31000 \\
Lavandula stoechas & 13000 \\
Lawsonia inermis & 10000 \\
Anacyclus pyrethrum & 10000 \\
Medicago sativa & 10000 \\
Salvia officinalis & 5400 \\
Trigonella foenum-graecum & 5000 \\
Papaver rhoeas & 3500 \\
Origanum vulgare & 3200 \\
Citrus aurantium & 3000 \\
Iris germanica & 2500 \\
Juniperus communis & 2500 \\
Mentha spicata & 2000 \\
Verbena officinalis & 2000 \\
Pelargonium capitatum & 1500 \\
Mentha piperita & 1000 \\
Rosa centifolia & 1000 \\
Chenopodium ambrosioides & 1000 \\
Cuminum cyminum & 1000 \\
Foeniculum vulgare & 800 \\
Pimpinella anisum & 500 \\
Santolina rosmarinifolia & 400 \\
Carum carvi & 200 \\
Total annual prod.(kg/ Year) & 494100 \\
\hline
\end{tabular}

year. The lowest quantities of mass production (1\% of the total production) returns to the following species: Papaver rhoeas, Origanum vulgare, Citrus aurantium, Iris germanica, Juniperus communis, Mentha spicata, M. piperita, Verbena officinalis, Pelargonium capitatum, Rosa centifolia, Potentilla anserina, Cuminum cyminum, Foeniculum vulgare, Pimpinella anisum, Santolina rosmarinifolia and Carum carvi.

The low yield of these spontaneous species can be explained by the weak natural regeneration of the species which originates in the general degradation of the ecosystems in Morocco, (SAIDI \& al., 2007). Consequently, the economic demand and the price of these species decrease with the increasing degradation of the natural environment. This encourages the cooperatives and associations to cultivate these species. In addition, they should improve the action plan upstream the sector of the MAP and support the competitiveness of products in order to maintain food security and increase the socio-economic income of the rural and marginalized population.

\section{YIELDS OF PRODUCTS BY COOPERATIVE AND ASSOCIATION}

Figure 2 shows that the Ajaâboo cooperative in the rural district of Ain Louh is leading the exploitation of the species with a total annual quantity of 120 tons, that is $19 \%$ of the total production of the area. The Ikiss cooperative in the Tatiouine zone near Midelt also produces 112 tons/year (18\% of the total production of the area).

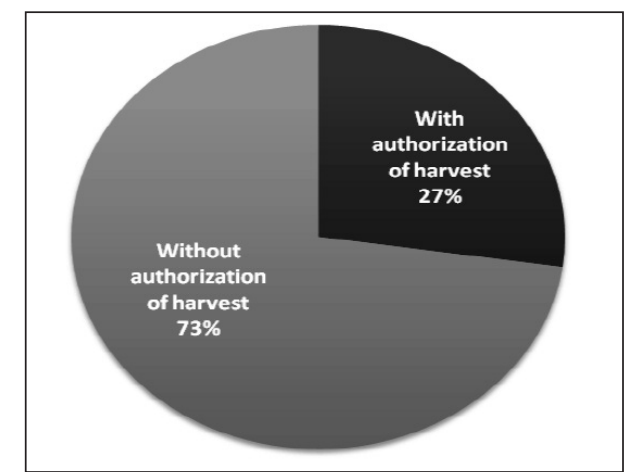

Figure 1.- Distribution of the exploitation type (wild or cultivated) and percentage of those with or without authorization of harvest of MAP species.0 


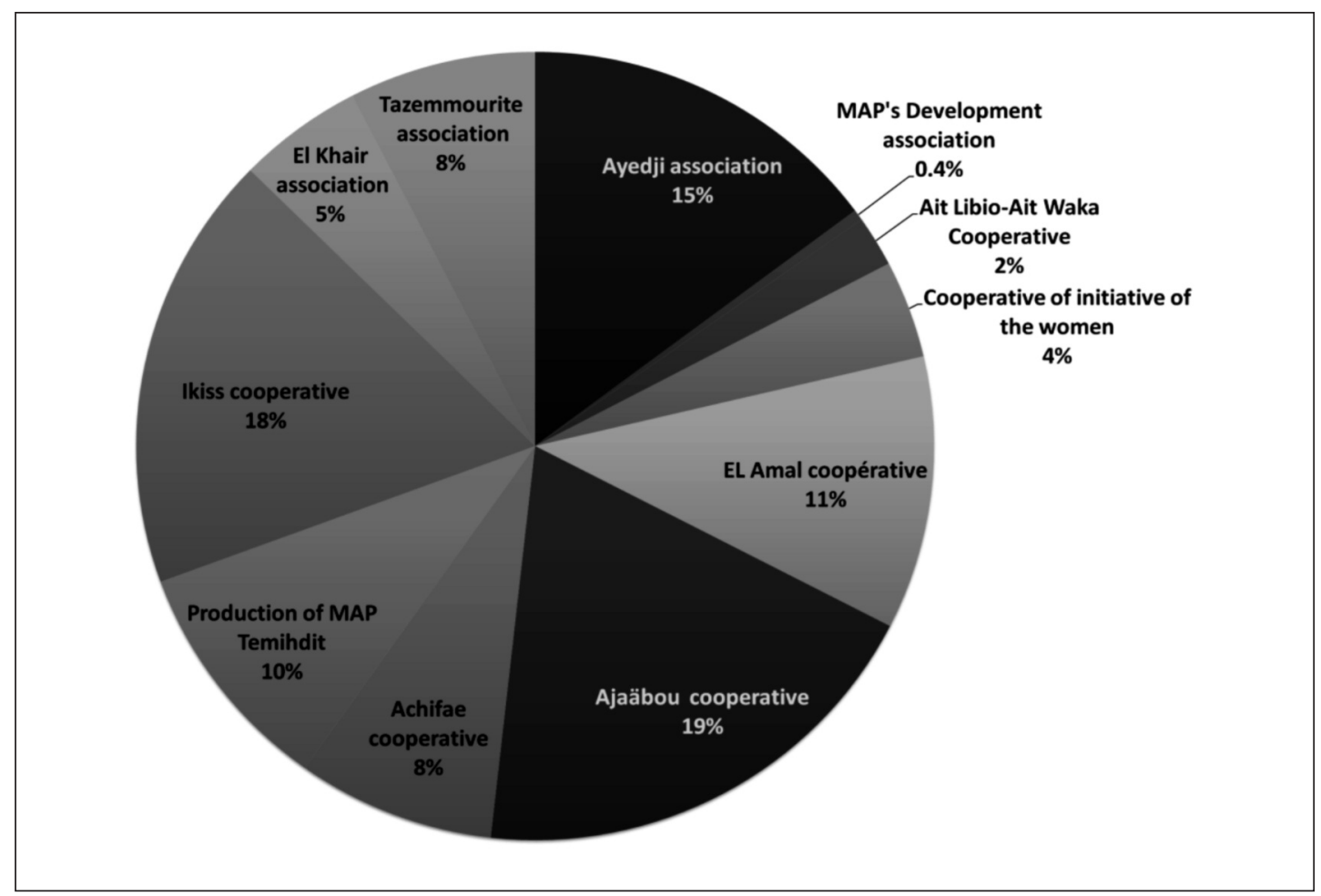

Figure 2. - Percentage of total annual production in mass of the species exploited by the cooperatives and associations of the Meknès-Tafilalt area.

The third position is occupied by the Ayedji association by an exploited quantity of 92.4 tons/ year of plants and a percentage of $15 \%$ of the total production of the area. These very important resources must be directed towards a comprehensive industrial exploitation. The private companies can be interested in this operating process since they can work with several cooperatives to ensure regular supplies. The role of state authorities consists in guaranteeing the improvement of the flow of information through the organization of several workshops and seminars which will allow the encounter between different actors of the sector. (ANON., 2006b).

It should be noted that most producers do not have a clear idea on the price of the products (the dried sheets) and sell them at weak price. The price varies according to the availability of the product, the market demand and the lack of traceability. So, the sector must be the object of a national debate implying all the stakeholders, in particular, the High Commission with National Forestry Com- mission and the Fight Against the Desertification, the Ministry for Agriculture and Maritime fishing, the Department of Rural Affairs under the Ministry of the Interior, the professionals, the herbalists and the cooperatives, to provide support in the labeling and marketing to advertise the MAP products and to revive the Morocco label of quality. These actions would certainly make it possible to set a program that contributes efficiently to the emergence of a new MAP industry by ensuring technical support for the producers to enable them to put products of good quality in the market at very competitive prices (ANON., 2006a).

\section{QUALIFICATION OF STAFF}

The inventory on the qualifications of staff shows that only two cooperatives, El Khair and Tazemmourite, that is to say $18 \%$ of all cooperatives and associations, received training qualification for their staff. The lack of knowledge of best practices in harvesting can damage the qua- 
lity of the collected products and productions of the following year (AssoumOu-NDONG, 2010) affecting, thus, the income of the population.

Harvesting practices will have to ensure the long-term survival of wild populations and habitats associated with them. Reinforcement of national competences and training of a sufficient qualified staff in the concerned (central, regional and local) administrations or on the ground (sensitizers) is a vital and critical need to achieve the goals of conservation and durable use of the living resources (ANON., 2004). Those responsible for harvesting must also receive instructions on all matters relating to environmental protection and the conservation of plant species as well as the benefits from the social point of view to ensure sustainable harvesting of wild medicinal plants. The prevention of environmental degradation is essential for the sustainable use of medicinal plant resources (ZHANG, 2003). The qualification of staff must also take into account the management and operation of the production units of MAP and their derived products. This training will be provided in the vocational training institutions and is largely based on practice (preparation of phyto-mass for the processing operations, use of distillation equipment, filtering and packaging of processed products, essential oils and extracts) (ANON., 2008).

\section{TECHNIQUES OF TREATMENT, CONDITIONING AND VALORIZATION OF THE EXPLOITED SPECIES}

All the cooperatives and associations carry out a sorting of the collected vegetable matter but only one cooperative, Aît Libio-Aît Waka, performs a specific treatment of the plants. The treatment under shade is, however, the most used means for drying the plants (Figure 3 ). Some producers have a drying machine but do not master the techniques of drying, which can affect chemical composition of the plants (SILOU \& al., 2002). Only two producers use the drying by sun method, which remains the less recommended means.

The valuation of exploited species is limited to the production of dry matter by the majority of producers. This type of operation exceeds $64 \%$ of harvested plants (Figure 3). Less than $36 \%$ of farmers value the species essential oils. No cooperative and no association have a data sheet on the quality and quantity of essential oils by species.

To make better use of exploited species, it is necessary first of all to take care of the production of the biomass. This can only be achieved through submission of operating with government regulations that allow a better management of the species and a protection of the resources, preserving the already exploited species and developing the exploitation of species with very poor yield. The processing methods are the key to a good valorization. In the case of our study, almost all of the essential oil extraction units are traditional, except cooperatives Libio Ait Ait-Waka and Ayedji which feature modern stainless steel extractor unit, equipped with a boiler for generating steam. This differential extraction technique is due to the cost of modern equipment for extracting oil and weak financial capacity of these organizations.

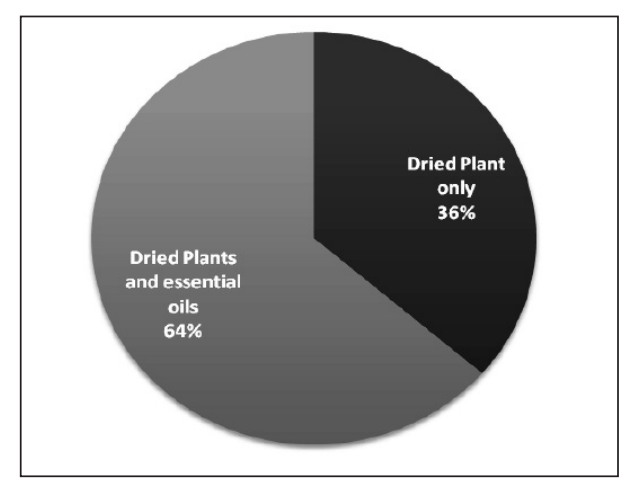

Figure 3. - Percentage of use of the various modes of treatment for the drying of the plants and percentages of valorization of the species exploited by the studied organizations. 
Therefore, state authorities must ensure the equipment of these operators with modernized distillation equipment necessary for their activity. This operation will certainly guarantee a competitive quality product. The authorities are also required to develop partnership agreements with donors to provide the necessary financial support for the purchase of distillation equipment (ANON., 2008).

Other forms of valorization are also common, such as the use of derivatives of the species in some local products of local soil as part of medicinal and / or culinary recipes such as herbal teas, bread, sauce, butter, honey, dates and couscous flavored with plants (EL RHAFFARI \& al., 2008). An adequate packaging of the products can also lead to a better valorization. The plants recovered after distillations are used as fuels for a new distillation. Mixed with some other products, they can also represent an interesting source of food for cattle that can be particularly developed in the period of welding. (ANON., 2006a).

Biological certifications would add value to MAP products of production/exploitation areas. It therefore becomes imperative to establish the Moroccan regulations of biological certification and the national certification of management systems. These regulations shall specify the procedures for certification and control of MAP and their biological derivatives. Progress in terms of routes management and traceability systems can lead to improvements in quality, food safety and environmental protection (ANON., 2006c).

Traceability and biological certification of products associated with adequate quality management can ensure industrial development of these products. This value is the primary objective of the operators. In fact, many plants can justify industrial exploitation as food flavors, fragrance components or cosmetic compositions, intermediaries of synthesis, herbal recipes or natural pesticides (BISSANGOU, 1997).

\section{QUALITY ASPECTS OF THE COMMERCIAL AND SOCIAL PRODUCT}

The results of the questionnaire for this section show that all producers do not practice a system of traceability for their products or biological cer- tification. They also lack a clear vision for the promotion and improvement of the sector, do not target the international market and do not have a vision of conservation of natural resources. It also shows that the sector is characterized by the presence of intermediaries who are the first to benefit from the present situation. Despite their creation by the state, these organizations still suffer from lack of support and assistance for technical guidance and research channels of marketing. For all these reasons, these organizations do not draw the benefits that allow populations to have a sufficient and steady income. Thus, improving the standard of living of the population through the development of the sector of MAP remains far from being achieved and is still binding under these adverse conditions.

\section{CONCLUSION}

In this study, the deep diagnosis allowed us to detect anomalies plaguing the sector of medicinal and aromatic plants in cooperatives and associations of the Meknes-Tafilalt region in Morocco. The results of this study show that $66 \%$ of harvested species are spontaneous and there is no request for permission to harvest and qualification of staff for almost all operators. This kind of exploitation and management of the harvest of the species can threaten the abundance and the durability of certain phytogenetic resources, namely: Rosmarinus officinalis and Matricaria chamomilla which respectively account for $23 \%$ and $14 \%$ of the total production. The type of exploitation of spontaneous plant resources may also contribute to the depletion and / or the disappearance of certain species of significant economic interest and medicinal importance as Foeniculum vulgare, Pimpinella anisum, Santolina rosmarinifolia or Carum carvi. A program of management and conservation of genetic resources must be considered in the sector of medicinal and aromatic plants. To support the competitiveness of products, meet market demand and increase socio-economic income of the rural and marginalized population, cooperatives and associations should incorporate culture in the 
sector of MAP. In the same sense, it is very useful to integrate training programs for the staff of the cooperatives and associations regarding good practice of harvest and quality, valorization, treatment and conditioning of the products of the exploited species, techniques of extraction, systems of certification and marketing and marketing of the final products.

\section{ACKNOWLEDGEMENTS}

The authors extend their special thanks to Professor Nadia Wahid from the National Institute of Medicinal and Aromatic Plants and for anonymous reviewers for their invaluable contribution to the improvement of this manuscript. The authors want Also to thank the administrative responsible of the Regional Directorate of Agriculture of Meknes Tafilalet area for their assistance in the collection of information on cooperatives and associations.

\section{REFERENCES}

Anonymous - 1996 - L'agriculture Dans La Région Meknès-Tafilalet Potentialités \& Opportunités D’investissement - Min. Agric. Marit. Fish. Dir. Prov. Agric., Meknès. Maroc.

Anonymous - 2000-Publication du plan de développement de la région de Meknès-Tafilalt 2000-2004 - High Comm. Plann. Rep. Dév. Econ., Rabat.

Anonymous - 2004 - Stratégie nationale pour la conservation \& l'utilisation durable de la Diversité Biologique Min. Reg. Plann. Water Environ., Rabat.

Anonymous - 2006a - Projet Filière Des Plantes Aromatiques \& Médicinales, Mission de l'USAID au Maroc Agric. Agrobuss. Int. Chemonics Int. Inc. Maroc.

Anonymous - 2006b - Maroc PAM, Lettre Bimensuelle d'Information sur les Plantes Aromatiques \& Médicinales - Un. St. Agen. Int. Dev., Rabat.

Anonymous - 2006c - Amelioration de la competitivite soutenable au Maroc, Mission de l'USAID au Maroc Agric. Agrobuss. Int. Chemonics Int. Inc. Maroc.

Anonymous - 2008 - Stratégie nationale de développement du secteur des plantes aromatiques \& médicinales Miss. US. Maroc. Agric. Agrobuss. Int. Chemonics Int. Inc. Maroc.

Assoumou-Ndong, F. - 2010- Promotion d'une économie d'entrepreneurs par la valorisation de la filière des plantes aromatiques \& médicinales (PAM) au Gabon Gabon. Sol. Int. Otawa, Canada.

Benabid, A. -2000 - Flore et écosystème du Maroc. Évaluation \& préservation de la biodiversité - Ibis Press. Paris.

Bissangou, M.F. \& Oljamba, J.M. -1997- Valorisation chimique de quelques espèces aromatiques \& médicinales du Congo - Pharm. Méd. Trad. Afr. 9: 70-84.

Cauvin, B., Marien, J.N. \& El-Yousfi, S.M. -1997- Protection, conservation \& gestion de ressources génétiques forestières au Maroc - An. Rech. For. Maroc. 1: 178195.

Eddouks, M., Maghrani, M., Lemhadri, A., Ouahidi, M.L. \& Jouad, H. -2002- Ethnopharmacological survey of medicinal plants used for the treatment of Diabetes mellitus, hypertension and cardiac diseases in the south-east region of Morocco (Tafilalet) - J. Ethnopharmacol. 82: 97-103.
El Amrani, F. \& Chakir, S. -2010 - Étude ethnopharmacologique de quelques plantes utilisées dans le traitement du diabète dans la région de Meknès-Tafilalet (Maroc) Phytother. 8: 161-165.

El Rhaffari, L., Allaoui, R., Benhssain, K. \& Sellam, K. 2008 - Valorisation des plantes aromatiques et médicinales des montagnes d'Er-Rachidia enquête ethnobotanique et socioéconomique - Errachidia Org. Non Gov., Italy. $39 \mathrm{pp}$.

González, J.A., García-Barriuso, M., Ramírez-Rodríguez, R., Bernardos, S. \& Amich, F. - 2012- Plants used in folk cosmetics and hygiene in the Arribes del Duero Natural Park (western Spain) - Lazaroa 33: 9-18.

Hmamouchi, M. - 1997- Plantes alimentaires, aromatiques, condimentaires, médicinales \& toxiques au Maroc - Cah. Opt. Medit. 23: 89-110.

Hseini, S., Kahouadji, A., Lahssissene, H. \& Tijane, M. 2007- Etude ethnobotanique de la flore médicinale dans la région de Rabat (Maroc occidental) - Lazaroa 28: 79-93.

Lahsissene, H. \& Kahouadji, A. -2010- Analyse ethnobotanique des plantes médicinales $\&$ aromatiques de la flore marocaine: cas de la région de Zaër - Phytother. 8: 202-209.

Mehdioui, R. \& Kahouadji, A. -2007 - Etude ethnobotanique auprès de la population riveraine de la forêt d'Amsittène : cas de la Commune d'Imi n'Tlit (Province d'Essaouira) - Bull. Inst. Sci. 29: 11-20.

Porres-Martínez, M., Carretero M.E. \& Gómez-Serranillos, M.P. - 2013 - Pharmacological activity of Salvia lavandulifolia Vahl. and chemical components of its essential oil - Lazaroa 34: 237-254

Saidi, S., Sebbata, O., Bencherqi, A., Mrabet, R. \& Oukabli, A. -2007- Rapport National Sur L'état des ressources phytogénétiques pour l'alimentation et l'agriculture Inst. Natl. Rech. Agron., Rabat.

Salhi, S., Fadli, M., Zidane, L. \& Douira, A. -2010 - Etudes floristique et ethnobotanique des plantes médicinales de la ville de Kénitra (Maroc) - Lazaroa 31: 133-146.

Scherrer, A.M., Motti, R. \& Weckerle, C.S. -2005 - Traditional plant use in the areas of Monte Vesole and Ascea, Cilento National Park (Campania, Southern Italy) - J. Ethnopharmacol. 97: 129-143. 
Silou, T., Taty-Loumbou, F. \& Chalchat J.C. -2002Etude de l'effet du séchage solaire sur le rendement \& la composition chimique des huiles essentielles extraites des feuilles d'Eucalyptus citriodora - Ann. Falsif. Expert. Chim. Toxicol. 960: 287-301.

Tahraoui, A., EL-Hilaly, J., Israili, Z.H. \& Lyoussi, B. 2007 - Ethnopharmacological survey of plants used in the traditional treatment of hypertension and diabetes in south-eastern Morocco (Errachidia province) - J. Ethnopharmacol. 110: 105-117.

Wahid, N., Heuertz, M., Alia, R., Boulli, A. \& García-Martínez, S.C. -2009- Exploration \& conservation des ressources génétiques du Pin maritime au Maroc - For. Médit. 3: 245-256.

Wahid, N., Naydenov, K.D., Kamari, S., Boulli, A., Tremblay, F. - 2010 - Structure genetic of Pinuspinaster Ait. populations in Morocco revealed by nuclear microsatellites - Biochem. Syst. Ecol. 38: 73-82.

Wahid, N., André, R., Lamhamedi, M.S., Beaulieu, J., Margolis, H.A. \& De Blois, J. -2012- Genetic parameters and performance stability of white spruce somatic seedlings in clonal tests - For. Ecol. Manag. 270: 45-53.

Wahid, N. -2012 - La diversité génétique des ressources naturelles à l'épreuve de la satisfaction des besoins écologique \& économique - Journées National de Substances Naturelles et Développement Durable, 22-23 Juin 2012, Rabat. Maroc.

Zhang, X. - 2003 - Directives OMS sur les bonnes pratiques agricoles et les bonnes pratiques de récolte (BPAR) relatives aux plantes médicinales - Dép. Méd. Ess. Polit. Pharm. WHO. Genève.

Received: 5 July 2013

Accepted: 15 September 2014 